\title{
IJMALI METHOD IN INTERPRETATION AL-QUR'AN
}

\author{
Hamid Sakti Wibowo \\ FAI Unwahas \\ hamidsaktiw@gmail.com
}

\begin{abstract}
Commentators who use this method usually explain the verses of the Qur'an briefly in popular language, easy to understand and easy to read. Mufasir will interpret the Qur'an directly from beginning to end. The interpretation given is not done extensively but concisely and generally so that the reader seems to be still reading the Qur'an when what is read is the interpretation. Methods are one of the most important means to achieve a set goal. In this regard, the method in the study of the interpretation of the Qur'an can be interpreted as an orderly and well thought out way to achieve a correct understanding of what God means in the verses of the Qur'an that He revealed to the prophet. Muhammad saw.
\end{abstract}

Keywords: ijmali method, interpretation of the Qur'an.

\section{INTRODUCTION}

The Qur'an is like a diamond in which each verse emits light. This gives the impression that the Qur'an is a source of inspiration that has inspired the emergence of volumes of tafsir books. The study of the tafsir of the Qur'an is absolutely necessary in order to know the meaning of Allah contained in all the commands and prohibitions that have been set for His servants, and to find and understand the guidance of Allah in the field of faith, worship, and morals. The emergence of various books of tafsir is inseparable from the differences in the methods of interpretation used by the commentators in interpreting the Qur'an.

Methods are one of the most important means to achieve a set goal. In this regard, the method in the study of the interpretation of the Qur'an can be interpreted as an orderly and well thought out way to achieve a correct understanding of what God means in the verses of the Qur'an that He revealed to the prophet. Muhammad saw ${ }^{1}$. So far, four methods used by commentators are known in interpreting the Qur'an, namely the method of ijmali (global), tahlili (analytical), muqarin (comparison), and maudhu'i (thematic). To increase the understanding of the method of tafsir here the author will explain about the method of ijmali with examples.

\footnotetext{
${ }^{1}$ Nashruddin Baidan, Metode Tafsir al-Qur'an, (Yogyakarta: Pustaka Pelajar, 2002), hlm. 55.
} 


\section{DISCUSSION}

A. Understanding the Method of Tafsir Ijmali

Literally, the word ijmali comes from the word ajmala which means to mention something in no detail ${ }^{2}$. In his book Mohammad Rifa'i entitled "Why Tafsir of the Qur'an is Necessary" The method of tafsir ijmali is defined as interpreting the meanings of the verses of the Qur'an briefly and globally, by explaining the meaning of each sentence with the language which is concise and easy to understand. In interpreting the verse, the commentator does not provide a detailed and adequate description, so generally the reader finds it difficult to find a detailed description ${ }^{3}$.

So the method of tafsir ijmali can be interpreted to explain the meaning of the verses of the Qur'an in general in accordance with the order of the letters in the mushaf without detailing it, or a brief explanation of the divine messages contained in a verse ${ }^{4}$. Commentators who use this method usually explain the verses of the Qur'an briefly in popular language, easy to understand and easy to read. Mufasir will interpret the Qur'an directly from beginning to end. The interpretation given is not done extensively but concisely and generally so that the reader seems to be still reading the Qur'an when what is read is the interpretation. In his tafsir, an interpreter uses the lafadz of a language that is similar and even the same as the lafadz of the language of the Qur'an.

In the systematics of the description, the interpreter will discuss verse by verse in accordance with the order in the manuscript, then present the global meaning meant by the verse. The meaning expressed is usually placed in a series of verses or according to patterns recognized by the majority of scholars'.

This method has similarities with the method of tahlili, which is to interpret the verses of the Qur'an based on the sequence of verses as the order in the mushaf. The difference with the tahlili method is in the ijmali tafsir of the meaning of the verse which is expressed globally and concisely, while in the tafsir tahlili the meaning of the verse is explained in detail with a review of various aspects and aspects that are

\footnotetext{
${ }^{2}$ Kadar M. Yusuf, Stdi al-Qur'an, (Jakarta: AMZAH, 2009), hlm. 145.
}

${ }^{3}$ Mohammad Rifa'i, Mengapa Tafsir al-Qur'an Dibutuhkan, (Semarang: CV Wicaksana, t.t), hlm. 40.

${ }^{4}$ Saiful Amin Ghofur, Mozaik Mufasir al-Qur'an dari Klasik hingga Kontemporer, (Yogyakarta: Kaukaba Dipantara, 2013), hlm. 14. 
reviewed at length. In tafsir ijmali, new sciences can be used such as using the hadiths of the Prophet, the opinion of the ulama 'salaf, historical events, asbabun nuzul, and the rules of language ${ }^{5}$.

For beginners or those who do not need a detailed description of the understanding of a verse, then the method of ijmali is very appropriate to use ${ }^{6}$. Interpretations that use this method feel more practical and easy to understand. Without being convoluted, the understanding of the Qur'an can be immediately absorbed by the reader. The weakness of this method in accordance with its short and global nature, is that it is not enough to lead the reader to dialogue the Qur'an with actual and problematic social and scientific issues.

In accordance with the explanation above, the characteristics of tafsir with the ijmali method are ${ }^{7}$ :

1. Interpret the verses according to the order of the manuscript.

2. Interpret the verses of the Qur'an from beginning to end without comparison and title determination.

3. Each letter is divided into groups of verses, then interpreted concisely and globally, although certain verses give a rather broad interpretation, but not in the analytical area.

4. The words and language are not far from the text of the Qur'an.

5. Mufasir does not present many opinions and ideas.

B. Examples of Interpretation with the Ijmali Method

Among the books of tafsir written according to the ijmali method are: Tafsir al-Qur'an al-Karim by Muhammad Farid Wajdi, Tafsir al-Wasith published by Majma 'al-Buhuts al-Ismiyyah, tafsir al-Jalalain by Jalaluddin as-Suyuti and Jalaluddin alMahalli, Shafwah al-Bayan li Ma'ni al-Qur'an by Hisain Muhammad Makhlut, and tafsir al-Wadhih by Muhammad Mahmud Hijazi ${ }^{8}$.

\footnotetext{
${ }^{5}$ Muhammad Nur Ichwan, Prof. M. Quraish Shihab Membincang Persoalan Gender, (Semarang: RASAIL Media Group, 2013), hlm. 54-55.

${ }^{6}$ Nashruddin Baidan, Metodologi Penafsiran al-Qur'an, (Yogyakarta: Pustaka Pelajar, 2005), hlm. 28

7 Ahmad Arif Junaidi, Pembaharuan Metodologi Tafsir al-Qur'an (Studi atas Pemikiran Tafsir Konteksstual Fazlur Rahman), (Semarang: CV Gunungjati, 2000), hlm. 25.

8 Abdullah al-Hayy al-Farmawi, Metode Tafsir Mawdhu'iy, (Jakarta: PT RajaGrafindo Persada, 1996), hlm. 30.
} 
One of the tafsir books that use the ijmali method is tafsir jalalain written by Jalaluddin as-Suyuti and Jamaluddin al-Mahalli. Here is an example of the Qur'an surat al-Baqarah verses 1-39

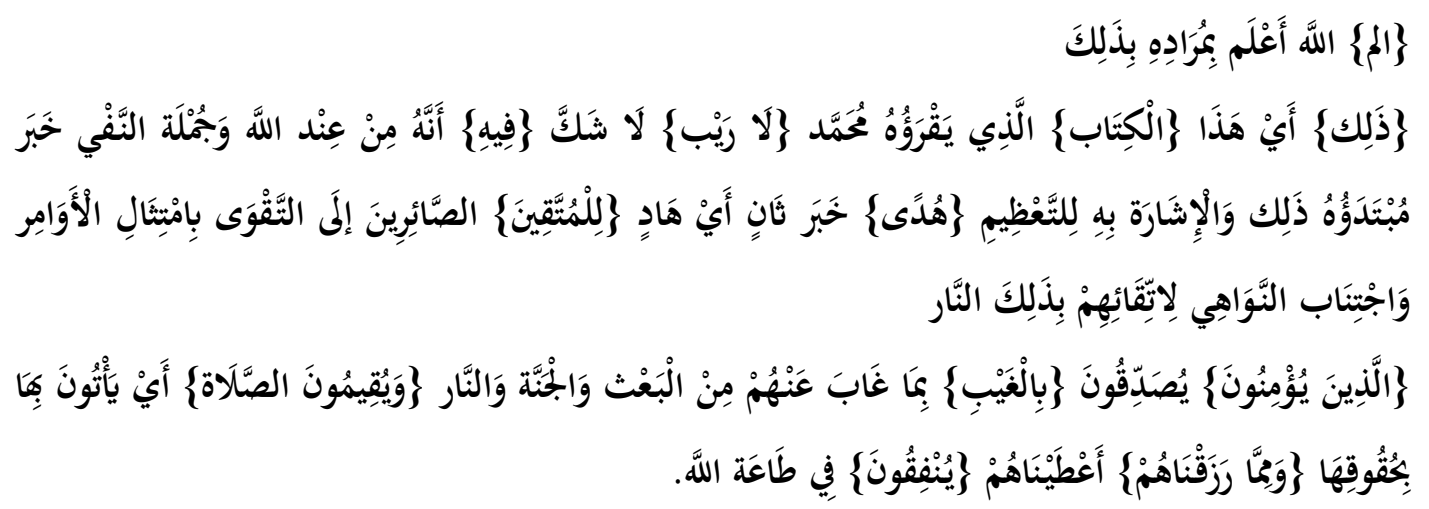

Alif Lām mīm = Allah who knows best about it.

Zālikal kitabu $=$ This is the book recited by Muhammad

Lāraiba fîh $\overline{1}=$ There is no doubt in it (the Qur'an), that the book came from Allah. (The number of denials is news, while the mubtada is Zālik. The words of zālik signal the greatness of Allah.

Hudan $=$ As the second news for zâlik, meaning the one who gives guidance.

Lilmuttaqin $=$ For those who are pious, that is, those who are always pious by fulfilling the commands of God and stay away from His prohibitions, because his piety is to avoid the punishment of hell.

Allazina yu'minūna $=$ Those who believe, are given tafsir, that is, those who believe with confidence.

Bilgaibi $=$ To the unseen, such as the resurrection in the hereafter, heaven and hell.

Wa yuqīmunas sholāta $=$ And they establish prayer, that is, meet the requirements of the pillars.

Wamimmā razaqnāhun $=$ And spend some of the sustenance we give.

Yunfiqūn $=$ They infakan in order to obey the command of Allah.

In addition to interpreting the wording of the words in the verse, it also always emphasizes i'rab and nahwunya. The above interpretation seems so brief and global that there

\footnotetext{
${ }^{9}$ Imamaini al-Jalalaini, Tafsir Jalalain, (Surabaya: Nurul Huda, t.t), hlm. 2-3.
} 
are no extensive explanatory details. Because the tafsir mentioned is the main thing, then with the guidelines of tafsir jalalain, the commentator will be spared from mistakes.

\section{CLOSING}

The method of tafsir ijmali is an explanation of the meaning of a verse of the Qur'an in general without detailing it, or a brief explanation of the Divine messages contained in a verse. In tafsir ijmali, new sciences can be used such as using the hadiths of the Prophet, the opinion of the ulama 'salaf, historical events, asbabun nuzul, and the rules of language. One of the famous tafsir books that use the ijmali method is tafsir jalalain written by Jalaluddin asSuyuti and Jamaluddin al-Mahalli. That's what my paper conveys. With the hope that it can be beneficial for all parties. I realize there are still many shortcomings in the writing of this paper. Therefore, criticism and suggestions are needed for the benefit of us all. And hopefully we can take the wisdom.

\section{DAFTAR PUSTAKA}

Baidan, Nashruddin, Metode Tafsir al-Qur'an, Yogyakarta: Pustaka Pelajar, 2002.

-------, Metodologi Penafsiran al-Qur'an, Yogyakarta: Pustaka Pelajar, 2005.

al-Farmawi, Abdullah al-Hayy, Metode Tafsir Mawdhu'iy, Jakarta: PT RajaGrafindo Persada, 1996.

Ghofur, Saiful Amin, Mozaik Mufasir al-Qur'an dari Klasik hingga Kontemporer, Yogyakarta: Kaukaba Dipantara, 2013.

Ichwan, Muhammad Nur, Prof. M. Quraish Shihab Membincang Persoalan Gender, Semarang: RASAIL Media Group, 2013.

Imamaini al-Jalalaini (Jalaluddin as-Suyuti dan Jamaluddin al-Mahalli), Tafsir Jalalain, Surabaya: Nurul Huda, t.t.

Junaidi, Ahmad Arif, Pembaharuan Metodologi Tafsir al-Qur'an (Studi atas Pemikiran Tafsir Konteksstual Fazlur Rahman), Semarang: CV Gunungjati, 2000.

Rifa'i, Mohammad, Mengapa Tafsir al-Qur'an Dibutuhkan, Semarang: CV Wicaksana, t.t. Yusuf, Kadar M., Stdi al-Qur'an, Jakarta: AMZAH, 2009. 